\title{
Model składni semantycznej w badaniach historycznojęzykowych Możliwości i perspektywy
}

Słow a klucze: składnia; diachronia; metodologia; semantyka; struktura predykatowo-argumentowa

K e y w ord s: syntax; diachrony; methodology; semantics; predicate-argument structure

Uchwycenie zmian składniowych i opisanie tendencji, które leżą u ich podłoża, jest podstawowym zadaniem historyka języka zajmującego się rozwojem struktur syntaktycznych każdego języka. Już kilkadziesiąt lat temu Krystyna Pisarkowa pisała: „Teorie języka będą niezadowalające, dopóki nie stać nas będzie na sformułowanie „systemu” tendencji. Pewne jest bowiem, że wszystkie systemy naturalne zawierają w sobie tendencje dynamiczne. To właśnie sprawia, że historia składni trwa aż do dziś, a nawet dalej, ponieważ składnia ta zawiera w sobie programy własnych możliwości ewolucyjnych" (Pisarkowa 1984: 10).

Poszukując odpowiedniego sposobu na opisanie zmian składniowych, historyk języka dąży do wymaganej przez paradygmat naukowy precyzji metodologicznej. Dysponuje jednak środkami, jak dotąd, niedoskonałymi. Wynika to z faktu, iż korzysta z metodologii wypracowanych na gruncie badań 
synchronicznych. Postępowanie takie ma swoje uzasadnienie, wszak badania synchroniczne dają oparty na określonej metodologii oraz kompetencji językowej obraz systemu językowego, który jawi się jako logiczny konstrukt złożony z szeregu reguł spełniających warunki poprawności semantycznej i gramatycznej. Jak pisze K. Pisarkowa: „sama synchronia jest podobnie jak pojęcie systemu językowego przydatną abstrakcją naukową" (Pisarkowa 1984: 10). Przydatną jednak do pewnego stopnia: „Trudno gdziekolwiek i kiedykolwiek wyraźniej dostrzec umowność koniecznych zabiegów teoretycznych składni niż $\mathrm{w}$ analizie składni języka mówionego lub $\mathrm{w}$ analizie historycznej. Wszystkie klasyfikacje części zdań, a także samych zdań, okazują się uproszczeniem, które niezbyt łatwo przystają do rzeczywistości. Podstawowe opozycje wyróżniane zazwyczaj w składni langue tracą swoje ostre kontury choćby dlatego, że na tym właśnie polega ewolucja obserwowanych faktów czy jednostek składniowych" (Pisarkowa 1984: 9).

W dotychczasowych opracowaniach składni historycznej języka polskiego dominują dwa kierunki badawcze: składnia tradycyjna i klasyczna strukturalna (por. Walczak 2012, Grochowski 2012), a syntezy składniowe powstające na gruncie obu teorii spełniać miały różne cele. Albo koncentrowały się na opisie struktur nieciągłych, albo całą uwagę kierowały na rozwój polszczyzny literackiej, składnię średniowieczną traktując jako kontynuację stanu prasłowiańskiego ${ }^{1}$. Przyjęcie odmiennej perspektywy badawczej, umożliwiającej formułowanie pytań o tendencje w składni - nie tylko z perspektywy formalnej, ale i semantycznej - pozwoli wskazać najważniejsze obszary, w których zmiany zachodzą, uwypuklić najważniejsze procesy, wreszcie uwarunkowania z nimi związane. W Składni średniowiecznej polszczyzny (Krążyńska, Mika, Słoboda 2015) przedstawiliśmy zespół tendencji, które wyprowadziliśmy drogą indukcji na podstawie analizy przekształceń konstrukcji składniowych występujących w tekstach staropolskich, przy szerokim uwzględnieniu specyfiki tychże tekstów i wywołujących zmiany składniowe czynników zewnętrznych (tu głównie proces upiśmiennienia). Określiliśmy je następująco:

${ }^{1}$ Ich omówienie znalazło się w Krążyńska, Mika, Słoboda 2015: 13-17, por. też Kleszczowa 2006. 
1. Tendencja analityczna (od holizmu do analityzmu);

2. Tendencja do autonomizacji języka (odrywanie się języka od rzeczywistości pozajęzykowej);

3. Kategoryzacja (od semantyki leksykalnej do semantyki kategorialnej ujętej w formę);

4. Strukturyzacja (od apozycji do związków składniowych);

5. Kondensacja treści (od ubogiej treści jednostek składniowych do kumulacji treści w jednostkach).

Tendencje te sytuujemy na najwyższym, abstrakcyjnym poziomie opisu, do którego można się odwołać, interpretując konstrukcje składniowe i ich przekształcenia występujące $\mathrm{w}$ badanych tekstach. Oczywiście procesów składniowych jest bardzo wiele. Poszczególne tendencje mogą przejawiać się w różnych procesach, a poszczególne procesy mogą być interpretowane jako rezultat oddziaływania różnych tendencji. Spojrzenie na procesy z perspektywy tendencji pozwala dostrzec w ich obrębie pewne całości, które przy indywidualnym ujęciu są niewidoczne albo nie rysują się wyraziście. W tym sensie tendencje stają się głównym punktem odniesienia dla opisu i interpretacji dynamiki zmian językowych oraz uwidaczniających się w długiej perspektywie czasowej prawidłowości.

Dotychczasowe nasze wysiłki zmierzały do scharakteryzowania i zrozumienia zasadniczych zmian w składni staropolskiej, nie dążyliśmy do kompletności opisu i nie obejmowaliśmy refleksją wszystkich zjawisk i procesów. Mimo to w Składni średniowiecznej polszczyzny znalazły się wstępne analizy dwu zbiorów konstrukcji. Pierwszy z nich stanowi całość semantyczną i reprezentuje struktury wyrażające informacje o stanie nadawcy, drugi - mający charakter formalny - zawiera nominalizacje scharakteryzowane ze względu na ich funkcję składniową (Krążyńska, Mika, Słoboda 2015: 109-156). W obu przypadkach nie zastosowaliśmy jednak jednolitej metodologii opisu.

Celem artykułu jest odpowiedź na pytanie, czy i w jakim stopniu można wykorzystać model przedstawiony w części składniowej Gramatyki wspótczesnego języka polskiego $(1984)^{2} \mathrm{w}$ badaniach historycznoskładniowych. Koreluje ono z postulatem Macieja Grochowskiego, który stwierdził, że „potrzebny i możliwy jest nowy opis składni języka polskiego, taki, dla którego punktem wyjścia byłaby koncepcja składni podstawowych struktur pre-

2 Dalej w tekście GWJPS. 
dykatowych Stanisława Karolaka (...). Opis oparty na tej koncepcji należy bowiem do najbardziej zdyscyplinowanych (...)" (Grochowski 2012: 150). Wykorzystanie tego modelu również w badaniach diachronicznych zaowocowałoby nie tylko całościowym opisem polszczyzny, ale stworzyłoby także możliwość dialogu i współpracy syntaktyków badających współczesny i dawny język polski³.

Zastosowanie składni semantycznej w badaniach diachronicznych jest możliwe, wymaga jednak poczynienia dodatkowych założeń, wynikających z różnic między statycznym i dynamicznym opisem języka. Zmiany w składni mogą być warunkowane różnymi czynnikami, ale przede wszystkim zmianami w umysłowości człowieka. Zarówno obserwacje antropolingwistyczne, jak i badania z zakresu ewolucji języka pokazują istotne różnice w postrzeganiu rzeczywistości przez ludzi w różnych okresach historycznych, wynikające ze zmieniających się warunków życia, doświadczenia, kształtowania zdolności intelektualnych. Nie chodzi tu o reprezentacje obecne lub nieobecne w danym języku ze względów kulturowych, ale o rozwój percepcji, który ma charakter uniwersalny. Procesy lateralizacji funkcji mózgowych i rozwój myślenia analitycznego, doświadczenia związane z upiśmiennieniem, zmianami kulturowymi i technologicznymi w późniejszych okresach, wpływały niewątpliwie na sposób postrzegania otaczającego świata, a tym samym na narzędzie do komunikowania o nim ${ }^{4}$. Interpretując dzieje składni, tego typu czynniki musimy brać pod uwagę. Konsekwencją takiego ujęcia jest objęcie dynamiką nie tylko warstwy wyrażeniowej. Założyć trzeba, że zmianom ulega również struktura semantyczna, pojęciowa, np. predykaty pierwszego rzędu przekształcają się w predykaty wyższego rzędu ${ }^{5}$. Zmiany te mogą za-

${ }^{3}$ Maciej Grochowski swój postulat kierował w stronę badaczy współczesnej polszczyzny, a do możliwości zastosowania modeli synchronicznych w diachronii kilkakrotnie w dyskusjach naukowych zgłaszał wątpliwości, wynikające głównie z braku kompetencji językowej w odniesieniu do dawnego języka polskiego.

${ }^{4}$ Nie sposób tu przywołać wszystkie prace z zakresu literatury przedmiotu. Przegląd najważniejszych koncepcji ewolucji języka daje m.in. Tecumseh Fitch (2010), na gruncie rodzimym dostępna jest praca omawiająca przede wszystkim hipotezy gesturalne (Żywiczyński, Wacewicz 2015). Bliska składni predykatywnej jest koncepcja Jamesa Hurforda (2012), do teorii gradualistycznych w opisie ewolucji składni odwołuje się Ljiljana Progovac, która w opisie sięga do modelu minimalistycznego Noama Chomsky’ego (Progovac 2015).

5 Wynika to z uniwersalnych zmian w umysłowości człowieka - od myślenia konkretnego do abstrakcyjnego, od holistycznego ujmowania rzeczywistości do analityzmu, 
chodzić pod wpływem warstwy wyrażeniowej, np. utrwalone w języku schematy składniowe powodują wykształcanie określonych cech konotacyjnych predykatu. Również obecność pewnych reguł we współczesnej składni nie oznacza automatycznie, że istniały one w okresach wcześniejszych. Tak jest chociażby z rekcją czasownika, która ukształtowała się wraz z odsemantyzowaniem kategorii przypadka (Mika, Słoboda 2015: 132).

Kolejnym ważnym założeniem jest, aby stosować konsekwentnie wszelkiego rodzaju kryteria pozwalające definiować określone klasy zjawisk we współczesnym języku. Przyjęcie innych kryteriów może powodować brak korelacji między opisem synchronicznym i diachronicznym. Chodzi tu głównie o części mowy ${ }^{6}$.

Postawą opracowania modelu semantycznego stały się teksty pisane. Autorzy piszą: „Zdecydowaliśmy się na opis gramatyczny polskiego języka ogólnego w zasadzie w jego postaci pisanej. Zaważył na tym wyborze nie tylko i nie przede wszystkim brak odpowiedniego korpusu tekstów mówionych w różnych dialektach kulturalnych, lecz przekonanie, że w znakomitej większości wypadków konstrukcje, które stanowią o specyfice języka mówionego, można i trzeba wyprowadzać z pełniejszych, bardziej eksplicytnych konstrukcji języka pisanego" (GWJPS: 6). W badaniach historycznych tekst pisany również jest podstawowym źródłem badań, ponieważ - co oczywiste - innych nie ma, ale towarzyszy im przekonanie, że odmiana pisana polszczyzny dopiero się kształtuje, zachowując wiele cech $\mathrm{i}$ konstrukcji typowych dla języka mówionego. Język najdawniejszych tekstów korzysta również z piśmiennego wzorca, ale obcego (łacińskiego, czeskiego, niemieckiego). Polszczyzna mówiona dopiero z czasem, pod wpływem rozpowszechniającej się odmiany pisanej może ulegać dalszym zmianom (por. Olson 2010). Eksplicytność w ujęciu diachronicznym ma zatem charakter dynamiczny. Wraz z kształtowaniem się pojęć językowych, naszego słownika umysłowego, rozbudowuje się repertuar form i konstrukcji składniowych. Perspektywa kierująca analizę od stanu obecnego do stanów dawnych powoduje, o czym często już wspominano, że w opisie historycznym wypełnia się nieistniejące, hipo-

od oralności opartej na przekazie fonicznym do piśmienności wykorzystującej postrzeganie wzrokowe.

${ }^{6}$ Dotyczy to tych części mowy i ich form, które w trakcie rozwoju języka zmieniają swój paradygmat bądź funkcję składniową, np. liczebników, imiesłowów, bezokolicznika, a także nieodmiennych wyrażeń funkcyjnych (por. Kleszczowa 2015). 
tetyczne luki w schemacie składniowym. Model odnoszący się do współczesnej polszczyzny traktować zatem należy jako opis języka w punkcie dojścia. Ewolucyjne spojrzenie na składnię zakłada także, że w języku nawarstwiają się konstrukcje powstałe w różnych okresach rozwojowych, będące wynikiem procesów o odmiennym charakterze. Jak pisaliśmy, „w każdym stanie aktualnym możemy odnaleźć ślady stanów przeszłych” (Krążyńska, Mika, Słoboda 2015: 19) ${ }^{7}$.

Mimo że GWJPS, zgodnie z deklaracją Autorów, nie jest gramatyką normatywną, stanowi modelowe przedstawienie systemu językowego ograniczonego normą uzualną (GWJPS: 6). Na każdym poziomie opisu składniowego stosowane są więc odpowiednie kryteria poprawnościowe, często oparte na kompetencji językowej. W analizie historyczno-składniowej musimy uwzględnić zmienność normy, a nawet jej brak związany - przede wszystkim w najdawniejszym okresie rozwoju polszczyzny - z powolnym kształtowaniem się pisanej odmiany języka. I mimo że, co podkreśla Krystyna Kleszczowa, „niemożliwe jest uwolnienie się od własnej kompetencji językowej” (Kleszczowa 2015: 26), należy być w pełni świadomym, że struktury tożsame formalnie i obecne w dawnych i współczesnych tekstach niekoniecznie reprezentują tę samą strukturę semantyczną.

W Składni wyrażeń predykatywnych Stanisław Karolak pisał: „Przyjęta więc została hierarchia, w której składnia semantyczna (zbiór reguł łączliwości sensów wyrażeń) stanowiąca zbiór reguł uniwersalnych, występujących we wszystkich językach naturalnych, stanowi komponent podstawowy, dominujący nad składnią strukturalną - zbiorem reguł nie uniwersalnych, właściwych tylko poszczególnym językom i w tym sensie idiomatycznych" (GWJPS: 19), wcześniej formułuje też myśl, że reguły te są od siebie niezależne: „,W językach naturalnych nie istnieje wzajemnie jednoznaczna odpowiedniość między regułami semantyczno-składniowymi (...) a regułami formalno-składniowymi (...), ani też między tymi ostatnimi a regułami linearnego uporządkowania jednostek języka" (GWJPS: 17). Nie można się do końca z tym stwierdzeniem zgodzić. Ewolucja języka pokazuje zgodnie $\mathrm{z}$ tendencją do autonomizacji i kategoryzacji formalnej stopniowe oddzie-

7 Koncepcję pozostałości wczesnych faz rozwoju języka (fossils) sformułował Ray Jackendoff, który też przedstawił swoją wizję ewolucji języka od etapu holistycznego przez protojęzyk do języka analitycznego (Jackendoff 1999). 
lanie się od siebie reguł semantycznych i formalno-składniowych. Tendencja do kategoryzacji prowadzi do kształtowania się reguł formalno-składniowych, które mają na celu właśnie odwzorowanie relacji semantycznych - dzieje się tak w wypadku kategorii przypadka (chodzi o tzw. przypadki semantyczne), osoby, liczby, wykładników bezosobowości itd. Tendencja do autonomizacji języka widoczna jest w procesach odrywających schemat formalno-składniowy od relacji semantycznych (np. forma wyrażeń predykatywnych przy grupach nominalnych kwantyfikowanych ilościowo, kształtowanie się rekcji czasownika) (Krążyńska, Mika, Słoboda 2015: 94-100; Mika, Słoboda 2015: 120-141). Opis dynamiki tych zmian jest również celem analizy diachronicznej. Pozwala wskazać z jednej strony te cechy formalno-składniowe, związane z konotacją i akomodacją, które wynikają z semantyki poszczególnych elementów struktury predykatowej, z drugiej - wymagania determinowane przez nacechowanie kategorialno-gramatyczne (składnia ad sensum i ad formam $)^{8}$.

Wykorzystanie metodologii składni predykatowej przy uwzględnieniu wskazanych powyżej założeń daje historykowi języka zupełnie nowe możliwości analizy i opisu zmian składniowych.

Przy okazji badań historycznojęzykowych wielokrotnie wskazywano na istotne trudności, jeśli chodzi o wyznaczanie granic staropolskiego zdania. Brak interpunkcji, abrewiacje, wieloznaczność wyrażeń funkcyjnych - to tylko niektóre z czynników, które sprawiają, że transkrypcje średniowiecznych rękopisów różnią się zasadniczo w poszczególnych edycjach, szczególnie w odniesieniu do zdań złożonych (por. Mika, Słoboda 2015: 61-91). Przyjęcie założenia, że podstawową jednostką analizy jest wyrażenie zdaniowe będące formalną realizacją struktury predykatowo-argumentowej (SPA) (z predykatem pierwszego lub wyższego rzędu) pozwala skupić się na relacjach semantycznych łączących zdania proste w wyrażeniach polipredykatywnych i modyfikacjach formalno-składniowych wynikających z procesów strukturalizacyjnych. Oczywiście w przeciwieństwie do modelu, obiektem badań stanie się przede wszystkim zdanie kontekstowe - uwikłane często w zależności wykraczające poza granice SPA. Wciąż też problematyczne będą te

8 Prowadzi to do występowania nawet w obrębie jednego tekstu konstrukcji wariantywnych, np.: Ale pięć s nich bylo szalonych a pięć mądrych. Tedy pięć mądrych nabraty oleju w swoje lampy, ale pięć szalonych wziąwszy lampy nie wzięty oleju z soba Rozmyślanie przemyskie 487. 
konstrukcje, w których zdania składowe lub proste pozostają w związku luźnym. Niemniej jednak, interpretacja wydawcy tekstu staropolskiego, uwidoczniona w transkrypcji, przestanie mieć dla analizy składniowej charakter podstawowy, o wiele bardziej wzrośnie natomiast znaczenie samego rękopisu i jego transliteracji.

Składnia semantyczna uwalnia historyka języka od tradycyjnie pojmowanych części zdania. To niewątpliwie nie tylko upraszcza opis, ale także zapobiega trudom ich identyfikacji. Wystarczy przypomnieć kwestię rozróżnienia dopełnienia od okolicznika, czy różnych podmiotów (gramatyczny, logiczny, epistemiczny). Opierając się na zaproponowanym modelu zdania elementarnego, można odróżnić elementy implikowane przez predykat bądź sam predykat od składników temporalnych, lokatywnych i modalnych, mimo że mogą mieć one takie same wykładniki formalne (zob. GWJPS: 215). W składni tradycyjnej elementy te umieszczane były w tych samych klasach funkcjonalnych - okoliczników i partykuł. Odróżnienie wyrażeń czasowych i lokatywnych w pozycji argumentowej i nieimplikowanej oraz predykatów modalnych od składników modalnych, a także podział predykatów na predykaty pierwszego i wyższego rzędu powoduje, że wzajemne zależności między zdaniem prostym i złożonym oraz parataksą i hipotaksą rozpatruje się $\mathrm{z}$ innej perspektywy ${ }^{9}$.

Operowanie na dwu poziomach - struktury semantycznej i wyrażeniowej - pozwala wyraźniej uchwycić ich wzajemne zależności wynikające z kategoryzacji semantyczno-formalnej a także stopniowe uzależnianie reguł łączliwości poszczególnych wyrażeń od hierarchii składników w schemacie formalno-składniowym (strukturyzacja). Opis procesów będących odzwierciedleniem określonych tendencji w ramach modelu semantycznego będzie w związku z tym inaczej uporządkowany w stosunku do składni tradycyjnej. W pierwszej kolejności należy poświecić uwagę predykacji i wyrażeniom predykatywnym konstytuującym zdanie. Ważne dla nas zjawiska związane $\mathrm{z}$ tendencją do kategoryzacji dotyczą predykacji imiennej, a w jej ramach

9 Ważna chociażby w wypadku elementów lokatywnych staje się charakterystyka predykatu, który implikuje lub nie obecność takiego wyrażenia. Dla opisu składniowego jest to istotne, ponieważ forma elementów stanowiących ramę lokatywną nie jest w żaden sposób uwarunkowana składniowo, ale wynika z ustabilizowania schematu składniowego ukształtowanego w konstrukcjach z argumentem lokatywnym implikowanym przez np. czasowniki ruchu. 
kategorii przypadka. Zmiany w tym zakresie muszą być opisane w kontekście stopniowego przechodzenia od kultury oralnej do piśmiennej, które mają wpływ także na procesy związane z tendencją analityczną. Wzrost roli predykacji werbalnej a w efekcie stabilizacja określonych schematów konotacyjnych ma swoje dalsze konsekwencje dla składni wyrażeniowej całej struktury predykatowo-argumentowej. Założenie, że jedna struktura predykatowo-argumentowa może być reprezentowana w różny sposób na płaszczyźnie formalnej umożliwia (szczególnie przy wyrażeniach predykatywnych wyższego rzędu) opis wariantywnych konstrukcji wykorzystywanych do wyrażania określonych relacji. Z jednej strony pozwala uchwycić formalną zmianę językową (np. wprowadzanie konstrukcji przyimkowych w miejsce kazualnych), z drugiej - kształtowanie się wariantów funkcjonalnych powiązanych ze stylistyką poszczególnych odmian językowych ${ }^{10}$.

Uwzględnienie wariantów diatetycznych i stosunku konwersji jest równie istotne, pozwala bowiem na obserwację zmian jakie zachodzą w sposobie formalizacji struktur predykatowych z predykatami relacyjnymi ${ }^{11}$. Dla opisu wyrażeń argumentowych konieczne jest, według mnie, wprowadzenie do opisu bardziej rozbudowanej charakterystyki ról semantycznych.

Zagadnienia związane $\mathrm{z}$ formalizacją struktur predykatywnych obejmują również wyrażenia polipredykatywne z imiesłowami i bezokolicznikami. W obu przypadkach z perspektywy diachronicznej można mówić o transformacjach nominalizujących. Są to konstrukcje o największym stopniu integralności semantyczno-formalnej, w których do zdania z predykatem czasownikowym na zasadzie apozycji przyłącza się zdanie z predykacją sformalizowaną imiennie ${ }^{12}$. Opis procesów strukturyzacyjnych, które prowadzą do zmiany właściwości morfologiczno-składniowych wskazanych wyrażeń oraz do wykształcenia się określonych schematów formalno-składniowych może tłumaczyć ich klasyfikację jako nieodmiennych form czasownika.

${ }^{10}$ W wypadku odmiany urzędowej można wskazać np. duży udział nominalizacji (zob. Słoboda 2005).

11 W tym względzie istotnymi procesami są np.: kształtowanie się struktur biernych oraz konstrukcji bezosobowych, formowanie konstrukcji werbo-nominalnych opartych m.in. na czasownikach dać, uczynić itp. (zob. Krążyńska 1986). Zwrócić też należy uwagę na pojawiające się w ostatnich latach prace uwzględniające funkcjonalną perspektywę zdania w badaniach diachronicznych (zob. np. Sobotka 2014, 2015, w druku).

12 Tak interpretuje chociażby konstrukcje typu nominativus cum infinitivus Antoine Meillet (1958: 300). 
W Gramatyce współczesnego języka polskiego odrębna część poświęcona została składni grupy imiennej. Model przedstawiony przez Zuzannę Topolińską wykorzystałam, jeszcze w niedoskonały sposób, w pracy dotyczącej średniowiecznych rot sądowych (Słoboda 2005). Wnioski z analizy, ograniczone tylko do języka urzędowego, są jednak na tyle istotne, że rozszerzenie opisu, tak by uwzględniał pozostałe odmiany polszczyzny, a także wskazywał oddziaływanie określonych tendencji, wydaje się uzasadnione. Szczególnie ważne jest uwzględnienie zagadnień związanych z referencją wyrażeń argumentowych.

W artykule starałam się wskazać możliwości, jakie daje historykowi języka zastosowanie modelu predykatowo-argumentowego w badaniach ewolucji składni. Niewątpliwie konieczne jest m.in. uspójnienie i ujednolicenie kryteriów opisu wyrażeń prostych i złożonych oraz opracowanie składni $\mathrm{szyku}^{13}$. Powstanie nowej wersji gramatyki semantycznej otworzyłoby nowe perspektywy w badaniach nie tylko nad współczesną, ale i dawną polszczyzną. Przyjąć jednak należy wskazane założenia, które definiowałyby najistotniejsze różnice między opisem synchronicznym i diachronicznym. Do tej pory bowiem, jak słusznie pisała Anna Kałkowska: ,przy opisie (...) historycznych faktów językowych ustalenia terminologiczne mają wartość głównie pomocniczą i często prowadzą do sztucznego i nieadekwatnego do rzeczywistości szufladkowania materiału” (Kałkowska 1976: 86). Takie ryzyko oczywiście istnieje również przy przyjęciu modelu semantycznego, ale aby uzyskać spójny obraz ewolucji języka, trzeba oprzeć go na wspólnej siatce pojęć. Jak pisał Thomas Givón: „The synchrony and diachrony of grammar are twin faces of the same coin. To study one without the other is to gut both. By understanding how synchronic grammars come into being we also understand the cognitive, communicative, neurological and developmental universals that constrain diachronic change - and through it synchronic typology" (Givón 2015: xi).

13 Najważniejsze wady i braki GWJPS wskazał Maciej Grochowski w swoim wystąpieniu konferencyjnym (Grochowski 2016). 


\section{Bibliografia}

Fitch T.W., 2010, The Evolution of Language, Cambridge - New York: Cambridge University Press.

Givón T., 2015, The Diachrony of Grammar, Amsterdam-Philadelphia: John Benjamins Publishing Company.

Grochowski M., 2012, Główne kierunki badań syntaktycznych w Polsce w drugiej połowie XX wieku i na początku XXI wieku, w: M. Grochowski (red.), Językoznawstwo w Polsce. Kierunki badań i perspektywy rozwoju. Materiaty z sesji jubileuszowej Komitetu Językoznawstwa PAN, Warszawa: Bel Studio, s. 139-155.

Grochowski M., 2016, Gramatyka współczesnego języka polskiego. Składnia - historia $i$ wspótczesność, referat wygłoszony na konferencji: Od pojęcia do formy. Składnia semantyczna po 30 latach od wydania „Gramatyki współczesnego języka polskiego" (Toruń, 2-3 września 2016 r.).

GWJPS (1984), TopoliŃska Z. (red.), Gramatyka wspótczesnego języka polskiego. Składnia, Warszawa: Państwowe Wydawnictwo Naukowe.

HURFORD J.R., 2012, The Origins of Grammar. Language in the Light of Evolution II, Oxford-New York: Oxford University Press.

JACKENDOFF R., 1999, Possible stages in the evolution of the language capacity, Trends in Cognitive Sciences V, 3 No. 7, s. 272-279.

KaŁKowska A., 1976, Predykatywne konstrukcje niewerbalne w historii języka polskiego, w: J. Konieczna-Twardzikowa (red.), Studia z polskiej sktadni historycznej I, Wrocław-Warszawa-Kraków-Gdańsk: Zakład Narodowy imienia Ossolińskich.

Kleszczowa K., 2006, Poziomy zmian językowych, w: S. Borawski, M. Hawrysz (red.), Zielonogórskie spotkania polonistyczne 2005, Zielona Góra: Oficyna Wydawnicza Uniwersytetu Zielonogórskiego, s. 117-129.

Kleszczowa K., 2015, U źródeł polskich partykut. Derywacja funkcjonalna, przemiany, zaniki, Katowice: Wydawnictwo Uniwersytetu Śląskiego.

KrążYŃSKa Z., 1986, Orzeczenie wraz z dopetniajacym otoczeniem w staropolskim zdaniu: (na przykładzie wielkopolskich rot sadowych), Poznań: Wydawnictwo Naukowe UAM.

KrążyŃsKa Z., Mika T., SŁoboda A., 2015, Składnia średniowiecznej polszczyzny. Cz. I: Konteksty - metody - tendencje, Poznań: Wydawnictwo Rys.

Meillet A., 1958, Wstęp do językoznawstwa indoeuropejskiego, Warszawa: Państwowe Wydawnictwo Naukowe.

Mika T., SŁoboda A., 2015, Wyrażenia funkcyjne w średniowiecznej polszczyźnie z perspektywy sktadniowej. Wybrane problemy badawcze. Poznań: Wydawnictwo Rys. 
Olson D.R., 2010, Papierowy świat. Pojęciowe i poznawcze implikacje pisania i czytania, przeł. M. Rakoczy, Warszawa: Wydawnictwo UW.

PISARKowa K., 1984, Historia składni języka polskiego, Wrocław: Zakład Narodowy im. Ossolińskich.

Progovac L., 2015, Evolutionary Syntax, Oxford - New York: Oxford University Press.

SŁoboda A., 2005, Składnia grupy imiennej w staropolszczyźnie. Na przykładzie wielkopolskich rot sądowych XIV i XV wieku, Poznań: Wydawnictwo „Poznańskie Studia Polonistyczne".

SoвоткA P., 2014. Od zaimka do wyrażenia funkcyjnego. Dzieje prasłowiańskiego zaimka *vıs-akъ i jego kontynuantów, w: A. Moroz, P. Sobotka, M. Żabowska (red.), Maiuscula linguistica. Studia in honorem Professori Matthiae Grochowski sextuagesimo quinto dedicata, 141-161. Warszawa: BEL Studio.

Sовотка P., 2015. Współdziałanie podsystemów języka w perspektywie badań ety-

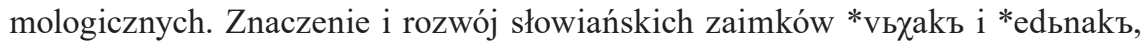
Linguistica Copernicana 12, s. 157-211, [online:] http://dx.doi.org/10.12775/LinCop.2015.007.

Soвотка P., (w druku), Jednostka opisu języka dawnego.

WalczaK B., 2012, Badania w zakresie historii języka polskiego (próba syntezy), w: M. Grochowski (red.), Językoznawstwo w Polsce. Kierunki badań i perspektywy rozwoju. Materiały z sesji jubileuszowej Komitetu Językoznawstwa PAN, Warszawa: Bel Studio, s. 99-111.

ŻYWICZYŃSKi P., WACEWICZ S., 2015, Ewolucjajęzyka. Wstronę hipotez gesturalnych. Toruń: Wydawnictwo Naukowe Uniwersytetu Mikołaja Kopernika.

\section{The semantic model of syntax in historical linguistics. Potentialities and prospects}

( summary)

In the article the author puts the question, is it possible to apply the semantic model of syntax to diachronic research. In the current works on historical syntax two research directions have dominated : traditional syntax and structuralism. These methodologies only, to some extent, made it possible to describe phenomena occurring in the development of the Polish syntactic constructions. The model presented in "Gramatyka współczesnego języka polskiego. Składnia” was collated with the conception of the medieval Polish syntax proposed by Krążyńska, Mika and Słoboda. The aim of the article is to indicate those syntactic phenomena which can be employed and those elements of the semantic model which are in need of modification to become a useful tool for diachronic interpretation of linguistic facts. The text constitutes one of many comments in the discussion about the relation between diachrony and synchrony in linguistics. 